\title{
Respon Fisiologis Domba Lokal Dengan Frekuensi Pemberian Pakan dan Taraf Konsentrat Limbah Ulat Hongkong (Tenebrio molitor) yang Berbeda
}

\author{
Physiological Response of Local Sheeps with Different of Feeding Frequency and Different Level of Tenebrio \\ molitor's Waste Concentrate \\ M. A. H. Kirjin ${ }^{1}$, S. Rahayu ${ }^{2 *}$, \& M. Baihaqi ${ }^{2}$ \\ ${ }^{1}$ Program Studi Teknologi Produksi Ternak, Program Sarjana, Institut Pertanian Bogor \\ ${ }^{2}$ Departemen Ilmu Produksi dan Teknologi Peternakan, Fakultas Peternakan, Institut Pertanian Bogor; Jln \\ Agatis Kampus IPB Dramaga Bogor 16680, Indonesia \\ *Email koresponden author : srirahy19@gmail.com \\ (Received 30-12-2019; Revised 13-01-2020; Accepted 24-01-2020)
}

\begin{abstract}
The aim of this research was to evaluate the effect of feeding frequency and level of Tenebrio molitor's waste concentrate (TMC) on the physiological response of local sheep. A total 18 rams aged Io (8 months) with an average body weight of $14.72 \pm 2.44 \mathrm{~kg}(\mathrm{CV} 16.91 \%)$ were used in this research. The reserch using 3x2 factorial randomized block design. Firts treatment was feeding frequency (2, 3 and 4 times/day) and second treatment was level of TMC ration $(70 \%$ and $35 \%$ of TMC). The variables observed were physiological responses (pulse rate, rectal temperature, and respiration rate). The data were analyzed by ANOVA. The results showed that there was interaction effect between feeding frequency and TMC level on pulse rate and rectal temperature of sheep. The level of 35\% TMC was significantly higher $(\mathrm{P}<0.05)$ on respiration rate than $70 \%$ TMC when the sheep feed in the morning. The research concluded that frequency of feeding and the level TMC had a significant effect on physiological responses in local rams.
\end{abstract}

Keywords : feeding frequency, Tenebrio molitor, pysiological response, local sheep

\section{ABSTRAK}

Tujuan penelitian ini adalah mempelajari efek frekuensi pemberian pakan dan taraf konsentrat limbah ulat hongkong pada respon fisiologis domba lokal. Penelitian ini menggunakan 18 ekor domba jantan usia I0 (8 bulan) dengan rataan bobot badan 14.72 $\pm 2.44 \mathrm{~kg}$. Penelitian didesain menggunakan rancangan acak kelompok pola faktorial 3x2. Fator pertama adalah frekuensi pemberian pakan (2, 3 dan 4 kali/ hari) dan faktor kedua adalah persentase limbah ulat hongkong yang berbeda $(70 \%$ dan $35 \%)$. Data dianalisis menggunakan analisis sidik ragam (ANOVA). Hasil penelitian menunjukkan bahwa terdapat interaksi antara waktu pemberian dan persentase limbah ulat hongkong yang diberikan. Pemberian ulat hongkong sebanyak 35\% signifikan lebih tinggi terhadap respirasi domba lokal. Sehingga dapat disimpulkan bahwa frekuensi pemberian pakan dan persentase limbah ulat hongkong sebagai konsentrat mempengaruhi respon fisiologis domba lokal.

Kata kunci: frekuensi pemberian pakan, limbah ulat hongkong, respon fisiologis, domba lokal.

\section{PENDAHULUAN}

Domba merupakan ternak prolifik (dapat beranak lebih dari satu untuk tiap kelahiran) yang mudah beradaptasi pada kondisi iklim setempat, sehingga pemeliharaan domba relatif mudah (Sumantri et al. 2007). Populasi ternak domba nasional tahun 2016 adalah sebanyak 15716695 ekor dan meningkat menjadi sebanyak 17142498 ekor pada tahun 2017 (Ditjen PKH 2018). Domba lokal merupakan domba yang dianggap mempunyai nilai ekonomis yang tinggi serta tahan terhadap cuaca panas dengan kelembaban tinggi. Meskipun demikian, ternak yang hidup di daerah tropis akan mendapatkan tambahan panas dari lingkungan yang tinggi, terutama pada siang hari (Al-Tamimi 2007).

Saat suhu lingkungan tinggi, ternak akan mulai mengurangi konsumsi pakan sebagai salah satu cara untuk mengurangi beban panas (Bhatta et al. 2006). Keadaan tersebut, akan mengakibatkan produktivitas ternak menurun 
karena banyak energi yang terbuang untuk menstabilkan suhu tubuh (Panagakis 2011). Isroli et al. (2004) menyatakan bahwa saat suhu dan kelembaban meningkat serta suhu lingkungan tidak sesuai dengan zona nyamannya, maka kebutuhan hidup pokok ternak akan meningkat, karena banyak energi yang digunakan untuk pelepasan panas tubuh ke lingkungan. Hal ini akan berdampak terhadap respon fisiologis domba, yang mana respon fisiologis merupakan salah satu indikator stres panas (Salsabila et al. 2014).

Konsentrat limbah ulat hongkong (Tenebrio molitor) dan limbah taoge diduga dapat memenuhi kehidupan pokok domba yang meningkat akibat banyak energi yang hilang. Konsentrat limbah ulat hongkong adalah konsentrat yang susunan ransumnya terdapat campuran kotoran ulat hongkong. Hasil uji laboratorium yang dilakukan di Departemen Ilmu Nutrisi dan Teknologi Pakan menunjukkan bahwa, konsentrat limbah ulat hongkong mengandung protein kasar sebesar $13.59 \%$, serat kasar $27.10 \%$, dan TDN (total digestible nutrient) $44.20 \%$. Limbah taoge merupakan hasil buangan dari pembuatan taoge yang berasal dari kacang hijau yang tidak dikonsumsi oleh manusia yang lebih dikenal dengan angkup taoge yang berwarna hijau. Limbah taoge sangat berpotensi dijadikan sebagai pakan ternak. Uji Kimia menunjukkan bahwa kandungan nutrisi limbah taoge cukup tinggi, yaitu mengandung protein kasar $13 \%-14 \%$, serat kasar 49.44\%, dan TDN (total digestible nutrient) 64.65\% (Rahayu et al. 2010). Semakin banyak kepala taoge yang tercampur maka kandungan nutrisi dari limbah taoge akan semakin tinggi.

Domba agar dapat tumbuh secara optimal, maka frekuensi pemberian pakan dan pakan yang digunakan harus diperhatikan. Konsumsi bahan kering seekor ternak juga harus menyesuaikan kapasitas atau daya tampung rongga perut (Mathius 2005). Hal ini dapat ditanggulangi dengan meningkatkan frekuensi pemberian pakan lebih dari dua kali dalam sehari. Frekuensi pemberian pakan yang lebih dari dua kali sehari diduga dapat meningkatkan konsumsi bahan kering pakan. Sumoprastowo (1986) menyatakan bahwa pemberian pakan pada ternak kambing dilakukan sedikit demi sedikit tetapi berulang kali, jadi semakin banyak frekuensi yang diberikan kepada ternak untuk mengkonsumsi pakan, maka makanan tersebut akan terserap secara sempurna di dalam tubuh ternak.

\section{MATERI DAN METODE}

\section{Waktu dan Tempat Penelitian}

Penelitian ini dilakukan di Laboratorium Lapang Bagian Ilmu Produksi Ruminansia Kecil Blok B, Departemen Ilmu Produksi dan Teknologi Peternakan dan Laboratorium Analisis Ilmu Nutrisi Ternak Daging dan Kerja, Departemen Ilmu Nutrisi dan Teknologi Peternakan, Fakultas Peternakan, Institut Pertanian Bogor. Penelitian dilaksanakan pada tanggal 8 September hingga 28 Desember 2018 .

\section{Prosedur}

Pertama kandang dibersihkan dan didesinfektan. Domba yang datang diistirahatkan selama 3 hari, kemudian dimandikan dengan campuran obat kutu lalu diberi obat cacing. Domba dikelompokkan berdasar bobot badan menjadi tiga kelompok yaitu $11.7 \pm 1.08 \mathrm{~kg}$ (A), $14.5 \pm 0.85$ $\mathrm{kg}$ (B), dan 17.12 $\pm 1.14 \mathrm{~kg}$ (C). Pengacakan dilakukan dengan mengundi setiap domba yang akan diberi perlakuan. Domba diberi masa adaptasi pakan dan lingkungan terlebih dahulu sebelum diberi perlakuan hingga domba terbiasa dengan pakan perlakuan dan lingkungan sekitar. Domba dipelihara secara intensif. Adaptasi pakan dan lingkungan dilakukan selama 14 hari. Domba kemudian mulai diberi perlakuan pakan K1 (30\% rumput Brachiaria humidicola $+70 \%$ konsentrat limbah ulat hongkong) dan K2 (30\% rumput brachiaria humidicola $+35 \%$ konsentrat limbah ulat hongkong $+35 \%$ limbah taoge).

Pemeliharaan dilakukan selama 90 hari dengan sistem intensif. Pakan yang diberikan setiap hari yaitu sebanyak 4\% bahan kering dari bobot badan. Ransum K1 dan K2 diberikan pada pagi dan siang hari, sedangkan sore hari diberikan rumput Brachiaria humidicola dalam bentuk segar. Pengamatan respon fisiologis dilakukan sebanyak dua kali yaitu pada awal, dan akhir pemeliharaan setelah domba diberi perlakuan. Pengamatan dilakukan pada pukul 06.00-07.00 WIB, 12.00-13.00 WIB dan 16.30-17.30 WIB. Pengamatan dilakukan secara duplo.

\section{Peubah yang Diamati}

1. Respirasi diukur dengan cara menghitung jumlah hembusan nafas dari hidung (Anjani 2013) selama 15 detik dengan bantuan stopwatch kemudian hasil perhitungan dikalikan empat;

2. Pengamatan denyut nadi dilakukan dengan cara menempatkan jari di arteri femoral yang terletak di kaki belakang (Adelodun 2012) selama 15 detik kemudian hasil dikalikan empat; dan

3. Suhu rektal diukur dengan cara memasukkan thermometer digital ke dalam rectum dan dibiarkan hingga suhu yang tertera tidak berubah kembali atau terdengar bunyi dari thermometer.

\section{Analisis Data}

Penelitian ini menggunakan rancangan acak kelompok pola faktorial $3 \times 2$. Faktor pertama adalah frekuensi pemberian pakan (dua kali pemberian pakan, tiga kali pemberian pakan dan empat kali pemberian pakan) dan faktor kedua adalah taraf pemberian pakan konsentrat ulat hongkong (K1 $=30 \%$ rumput Brachiaria humidicola $+70 \%$ konsentrat limbah ulat hongkong dan K2 = 30\% rumput brachiaria humidicola $+35 \%$ konsentrat limbah ulat hongkong $+35 \%$ limbah taoge). Model matematika yaitu:

$$
Y i j=\mu+\sigma i+\beta j+\sigma \beta i j+\alpha k+\varepsilon i j k
$$
Keterangan :
$\mu$ : rataan umum
$\sigma$ : faktor frekuensi pakan
$\beta$ : level ulat hongkong
$\sigma \beta$ : interaksi frekuensi dan level
$\alpha$ : kelompok
$\varepsilon$ : galat 
Data respon fisiologis yang diperoleh dianalisis ragam atau ANOVA (analysis of variances) dengan selang kepercayaan 95\%. Data respon fisiologis dianalisis ragam pada masing-masing waktu (pagi, siang, dan sore hari). Data hasil analisis dilanjutkan dengan uji banding berganda Duncan ketika ada pengaruh perlakuan. Data respon fisiologis dianalisis ragam menggunakan aplikasi SPSS.

\section{HASIL DAN PEMBAHASAN}

\section{Keadaan Umum Penelitian}

Pengaruh suhu dan kelembaban merupakan salah satu faktor penting yang dapat mempengaruhi secara langsung terhadap kondisi fisiologis, performa ternak maupun respon pertumbuhan. Suhu dan kelembaban merupakan dua faktor iklim yang sangat berpengaruh terhadap keseimbangan panas dalam tubuh ternak. Berikut rataan suhu, kelembaban, dan level stres panas di kandang Blok B selama penelitian disajikan pada Tabel 1.

Hasil penelitian diperoleh bahwa rataan suhu di kandang adalah sebesar $\left(27.21 \pm 1.29^{\circ} \mathrm{C}\right)$ dengan kelembaban sebesar (83.98 $\pm 4.71 \%$ ). Yousef (1985) menyatakan kondisi lingkungan nyaman (thermoneutral zone) untuk domba berkisar $22-31{ }^{\circ} \mathrm{C}$ dengan kelembaban di bawah $75 \%$. Hasil penelitian menunjukkan bahwa suhu di kandang masih dalam rentang suhu normal, sedangkan rataan kelembaban yang dihasilkan lebih tinggi dari nilai kisaran kelembaban normal untuk domba. Kelembaban udara yang tinggi diduga dapat menyebabkan domba mengalami gangguan respirasi serta meningkatnya laju respirasi domba.
Tabel 1. Rataan suhu, kelembaban dan level stres panas di kandang Blok B

\begin{tabular}{lcccc}
\hline Waktu & Suhu $\left({ }^{\circ} \mathrm{C}\right)$ & $\begin{array}{c}\text { Kelembaban } \\
(\%)\end{array}$ & Nilai THI* & $\begin{array}{c}\text { Level } \\
\text { Stres } \\
\text { Panas* }\end{array}$ \\
\hline Pagi & $24.89 \pm 0.79$ & $90.46 \pm 1.91$ & 24.58 & Agak berat \\
Siang & $30.79 \pm 1.32$ & $76.92 \pm 5.81$ & 29.62 & Ekstrim \\
Sore & $28.25 \pm 2.27$ & $84.57 \pm 6.40$ & 27.59 & Ekstrim \\
Rataan & $27.21 \pm 1.29$ & $83.98 \pm 4.71$ & 26.57 & Ekstrim \\
\hline
\end{tabular}

Keterangan : Pagi (07.00) WIB, Siang (13.00), Sore (17.00).

Rataan suhu $=((2 \times \mathrm{T} 07.00)+\mathrm{T} 13.00+\mathrm{T} 17.00) / 4$. Rataan kelembaban $=($ RH07.00 + RH13.00 + RH17.00)/3 (Handoko 1995). Perhitungan nilai THI dilakukan berdasarkan rumus menurut Marai et al. (2007). Nilai THI kurang dari 22.2 tidak mengalami stres panas; $22.2-23.3=$ mengalami stres panas sedang; $23.3-25.6=$ stres panas agak berat; lebih dari $25.6=$ ekstrim stres panas. THI: Themperature Humidity Index, RH: Relative Humidity.

Hasil Perhitungan THI didapat bahwa lingkungan di kandang termasuk ke dalam level stres panas agak berat pada pagi hari dan level ekstrim pada siang dan sore hari. Level stres panas meningkat seiring dengan peningkatan nilai THI. Efek ini menjadi semakin buruk ketika terjadi stres panas disertai kelembaban yang tinggi (Hafez 2002). Hal ini tentu berpengaruh terhadap jumlah pakan yang dikonsumsi dan performa domba.

Rataan pertumbuhan bobot harian domba yang dipelihara berkisar antara 38.49 \pm 8.41 gram hingga 47.23 \pm 11.78 gram (Thahirah et al. 2019). Nilai PBBH ini termasuk rendah, diduga energi dari pakan yang dikonsumsi

Tabel 2. Rataan respirasi pada domba lokal

\begin{tabular}{|c|c|c|c|c|c|}
\hline \multirow[t]{3}{*}{ Waktu } & \multicolumn{5}{|c|}{ Respirasi (kali menit $\left.{ }^{-1}\right)$} \\
\hline & \multicolumn{5}{|c|}{ Taraf Perbandingan Konsentrat } \\
\hline & Frekuensi Pemberian Pakan & $\mathrm{K} 1$ & $\mathrm{~K} 2$ & Rataan & Normal \\
\hline \multirow[t]{4}{*}{ Pagi } & Dua kali & $41.30 \pm 1.15$ & $49.30 \pm 3.06$ & $45.30 \pm 4.21$ & \\
\hline & Tiga kali & $42.00 \pm 8.72$ & $42.67 \pm 1.15$ & $42.33 \pm 4.94$ & \\
\hline & Empat kali & $40.00 \pm 3.46$ & $47.30 \pm 6.43$ & $43.65 \pm 4.95$ & \\
\hline & Rataan & $41.10 \pm 4.44 \mathrm{a}$ & $46.42 \pm 3.55 b$ & $43.76 \pm 4.70$ & \\
\hline \multirow[t]{4}{*}{ Siang } & Dua kali & $52.66 \pm 9.24$ & $60.00 \pm 5.29$ & $56.33 \pm 7.27$ & \\
\hline & Tiga kali & $49.33 \pm 10.26$ & $54.67 \pm 9.01$ & $52.00 \pm 9.64$ & $26-32$ \\
\hline & Empat kali & $50.67 \pm 5.03$ & $50.00 \pm 5.29$ & $50.33 \pm 5.16$ & \\
\hline & Rataan & $56.44 \pm 16.57$ & $54.89 \pm 6.53$ & $55.67 \pm 16.4$ & \\
\hline \multirow[t]{4}{*}{ Sore } & Dua kali & $57.33 \pm 2.31$ & $54.00 \pm 12.9$ & $55.67 \pm 7.61$ & \\
\hline & Tiga kali & $45.33 \pm 9.87$ & $46.67 \pm 9.87$ & $46.00 \pm 9.87$ & \\
\hline & Empat kali & $45.33 \pm 10.06$ & $56.67 \pm 9.45$ & $51.00 \pm 9.76$ & \\
\hline & Rataan & $50.89 \pm 9.05$ & $52.45 \pm 10.7$ & $51.67 \pm 9.91$ & \\
\hline
\end{tabular}

Pengamatan respon fisiologis pagi dilakukan pukul 06.00 - 07.00, siang pukul $12.00-13.00$ dan sore pukul 16.30 - 17.30 WIB. K1 : $30 \%$ rumput Brachiaria humidicola $+70 \%$ konsentrat limbah ulat hongkong. K2:30\% rumput brachiaria humidicola $+35 \%$ konsentrat limbah ulat hongkong $+35 \%$ limbah taoge. Angka pada kolom atau baris yang sama diikuti huruf $(\mathrm{a}, \mathrm{b})$ menunjukkan berbeda nyata untuk $(\mathrm{P}<0.05)$. 
digunakan untuk menstabilkan suhu tubuh akibat adanya cekaman panas dari lingkungan. Adanya cekaman panas di kandang diduga tidak berpengaruh terhadap kesehatan ternak. Hal ini dapat diketahui, bahwa secara umum domba yang dipelihara masih dalam keadaan sehat hingga akhir pemeliharaan. Hal ini dikarenakan domba sudah dapat beradaptasi dengan lingkungan setempat (daerah tropis). Silanikove (2000) menyatakan domba memiliki tingkat kepekaan lebih rendah terhadap stres panas dibandingkan dengan sapi.

\section{Respirasi}

Respirasi meliputi semua proses baik fisik maupun kimia bahwa hewan mengadakan pertukaran gas-gas di sekelilingnya khususnya gas $\mathrm{O}_{2}$ dan $\mathrm{CO}_{2}$ (Widjajakusuma 1986). Domba merupakan hewan homoetermal yang mempertahankan tubuhnya dalam kondisi seimbang dengan menghilangkan kelebihan panas dari tubuhnya ketika terpapar suhu tinggi. Hal ini disertai dengan beberapa fungsi biologis dengan meningkatkan laju respirasi ataupun panting sebagai reaksi nyata (Marai et al. 2007). Data hasil pengamatan laju respirasi domba UP3J disajikan pada Tabel 2.

Berdasarkan hasil pengukuran, respirasi domba UP3J memiliki nilai rataan diatas kisaran normal (secara keseluruhan). Menurut Frandson (1992), kisaran normal respirasi pada domba yaitu 26-32 kali menit ${ }^{-1}$. Isnaeni (2006) menyatakan bahwa peningkatan pada frekuensi nafas merupakan salah satu upaya ternak dalam melakukan mekanisme termoregulasi untuk menstabilkan suhu tubuh akibat adanya beban panas. Tingginya hasil rataan respirasi yang diperoleh, diduga dikarenakan faktor human yang berkontak langsung dengan domba saat pengukuran berlangsung. Silanikove (2000) mengukur tingkat stres panas berdasarkan laju respirasi tiap menit pada domba dengan uraian : stres panas ringan 40-60 respirasi tiap menit, stres panas sedang 60-80 respirasi tiap menit, stres panas tinggi 80-200 respirasi tiap menit, stres panas berat lebih dari 200 respirasi tiap menit. Hal ini menunjukkan bahwa domba UP3J yang diamati berada dalam kategori stres panas ringan.

Laju respirasi nyata $(\mathrm{P}<0.05)$ dipengaruhi oleh frekuensi perbandingan konsentrat pada pagi hari, yaitu domba yang diberi ransum K1 memiliki hasil yang berbeda dengan K2. Hal tersebut dimungkinkan karena ransum K2 mempunyai komposisi adanya penambahan limbah tauge yang mempunyai serat kasar lebih tinggi, yang secara tidak langsung meningkatkan metabolisme tubuh, sehingga domba membutuhkan laju pernafasan yang lebih tinggi untuk membuang panas tubuhnya.

\section{Denyut Nadi}

Denyut nadi diperoleh dengan menghitung frekuensi denyut nadi dengan cara menempatkan jari di arteri femoral yang terletak di kaki belakang domba (Adelodun 2012). Jantung merupakan organ berongga dengan otot yang mampu mendorong darah ke berbagai tubuh. Jantung berkontraksi secara periodik untuk menjamin kelangsungan sirkulasi darah. Kecepatan jantung dalam berkontraksi ini dipengaruhi oleh saraf, rangsangan kimiawi seperti hormon dan perubahan kadar $\mathrm{O}_{2}$ dan $\mathrm{CO}_{2}$ ataupun rangsangan panas (Isnaeni 2006).

Tabel 3. Rataan denyut nadi pada domba lokal

\begin{tabular}{|c|c|c|c|c|c|}
\hline \multirow[t]{3}{*}{ Waktu } & \multicolumn{5}{|c|}{ Denyut Nadi (kali menit ${ }^{-1}$ ) } \\
\hline & \multicolumn{5}{|c|}{ Taraf Perbandingan Konsentrat } \\
\hline & Frekuensi Pemberian Pakan & $\mathrm{K} 1$ & $\mathrm{~K} 2$ & Rataan & Normal \\
\hline \multirow[t]{4}{*}{ Pagi } & Dua kali & $107.30 \pm 13.6$ & $102.67 \pm 5.03$ & $104.99 \pm 9.32$ & \\
\hline & Tiga kali & $113.33 \pm 15.0$ & $104.00 \pm 19.1$ & $108.66 \pm 17.0$ & \\
\hline & Empat kali & $106.67 \pm 7.02$ & $125.33 \pm 3.46$ & $112.34 \pm 12.5$ & \\
\hline & Rataan & $109.10 \pm 11.9$ & $108.22 \pm 9.19$ & $108.66 \pm 10.5$ & \\
\hline \multirow[t]{4}{*}{ Siang } & Dua kali & $109.33 \pm 17.5 \mathrm{ab}$ & $89.33 \pm 4.62 \mathrm{a}$ & $99.33 \pm 11.1 \mathrm{a}$ & \\
\hline & Tiga kali & $115.33 \pm 17.9 b c$ & $114.67 \pm 7.57 \mathrm{bc}$ & $115.00 \pm 12.7 b$ & \\
\hline & Empat kali & $111.33 \pm 14.2 \mathrm{ab}$ & $135.30 \pm 4.16 \mathrm{c}$ & $123.32 \pm 9.17 b$ & $60-120$ \\
\hline & Rataan & $111.99 \pm 16.5$ & $113.10 \pm 5.45$ & $112.55 \pm 10.9$ & \\
\hline \multirow[t]{4}{*}{ Sore } & Dua kali & $124.67 \pm 14.1$ & $105.30 \pm 10.3$ & $114.99 \pm 12.1$ & \\
\hline & Tiga kali & $118.00 \pm 15.1$ & $96.67 \pm 9.24$ & $107.34 \pm 12.2$ & \\
\hline & Empat kali & $121.33 \pm 7.02$ & $124.00 \pm 6.93$ & $121.34 \pm 6.98$ & \\
\hline & Rataan & $120.45 \pm 12.1 \mathrm{a}$ & $108.66 \pm 8.81 \mathrm{~b}$ & $105.56 \pm 10.4$ & \\
\hline
\end{tabular}

Pengamatan respon fisiologis pagi dilakukan pukul 06.00 - 07.00, siang pukul 12.00 - 13.00 dan sore pukul 16.30 - 17.30 WIB. K1 : $30 \%$ rumput Brachiaria humidicola $+70 \%$ konsentrat limbah ulat hongkong. K2:30\% rumput brachiaria humidicola $+35 \%$ konsentrat limbah ulat hongkong $+35 \%$ limbah taoge. Angka pada kolom atau baris yang sama diikuti huruf (a,ab,bc,c) menunjukkan berbeda nyata untuk $(\mathrm{P}<0.05)$. 
Tabel 4. Rataan suhu rektal pada domba UP3J

\begin{tabular}{|c|c|c|c|c|c|}
\hline \multirow[t]{3}{*}{ Waktu } & \multicolumn{5}{|c|}{ Suhu Rektal $\left({ }^{\circ} \mathrm{C}\right)$} \\
\hline & \multicolumn{5}{|c|}{ Taraf Perbandingan Konsentrat } \\
\hline & Frekuensi Pemberian Pakan & $\mathrm{K} 1$ & K2 & Rataan & Normal \\
\hline \multirow[t]{4}{*}{ Pagi } & Dua kali & $39.05 \pm 0.29$ & $39.42 \pm 0.24$ & $39.24 \pm 0.27$ & \\
\hline & Tiga kali & $39.20 \pm 0.20$ & $38.80 \pm 0.38$ & $39.00 \pm 0.29$ & \\
\hline & Empat kali & $38.90 \pm 0.09$ & $39.32 \pm 0.49$ & $39.11 \pm 0.29$ & \\
\hline & Rataan & $39.05 \pm 0.19$ & $39.18 \pm 0.37$ & $39.12 \pm 0.28$ & \\
\hline \multirow[t]{4}{*}{ Siang } & Dua kali & $39.48 \pm 0.27$ & $39.32 \pm 0.10$ & $39.40 \pm 0.19$ & \\
\hline & Tiga kali & $39.48 \pm 0.16$ & $39.47 \pm 0.25$ & $39.48 \pm 0.21$ & \\
\hline & Empat kali & $39.32 \pm 0.30$ & $39.20 \pm 0.29$ & $39.26 \pm 0.29$ & $38.2-40$ \\
\hline & Rataan & $39.43 \pm 0.24$ & $39.33 \pm 0.21$ & $39.38 \pm 0.23$ & \\
\hline \multirow[t]{4}{*}{ Sore } & Dua kali & $39.65 \pm 0.22 b$ & $39.75 \pm 0.09 b$ & $39.70 \pm 0.31$ & \\
\hline & Tiga kali & $39.78 \pm 0.33 b$ & $39.10 \pm 0.22 \mathrm{a}$ & $39.44 \pm 0.26$ & \\
\hline & Empat kali & $39.62 \pm 0.38 b$ & $39.75 \pm 0.25 b$ & $39.69 \pm 0.32$ & \\
\hline & Rataan & $39.68 \pm 0.31$ & $39.53 \pm 0.19$ & $39.61 \pm 0.30$ & \\
\hline
\end{tabular}

Pengamatan respon fisiologis pagi dilakukan pukul 06.00 - 07.00, siang pukul $12.00-13.00$ dan sore pukul 16.30 - 17.30 WIB. K1 : $30 \%$ rumput Brachiaria humidicola $+70 \%$ konsentrat limbah ulat hongkong. K2 : 30\% rumput brachiaria humidicola $+35 \%$ konsentrat limbah ulat hongkong $+35 \%$ limbah taoge. Angka pada kolom atau baris yang sama diikuti huruf $(a, b)$ menunjukkan berbeda nyata untuk $(\mathrm{P}<0.05)$.

Berdasarkan pengukuran yang dilakukan, rata-rata hasil rataan denyut nadi domba UP3J masih dalam kisaran normal. Kisaran denyut nadi normal pada domba sekitar 60 - 120 kali per menit (Frandson 1992). Domba yang diberi pakan 4 kali dengan ransum K2 memiliki hasil pengukuran diatas normal, baik pagi (125.33 \pm 3.46 kali menit $\left.^{-1}\right)$, siang $\left(135.30 \pm 4.16\right.$ kali menit $\left.^{-1}\right)$ ataupun sore hari $(124.00 \pm 6.93$ kali menit $\left.{ }^{-1}\right)$. Hal ini diduga karena metabolisme yang tinggi terjadi karena pemberian pakan yang dilakukan 4 kali, diikuti dengan denyut nadi yang meningkat. Hasil pengukuran juga menunjukkan, bahwa rataan denyut nadi domba yang diberi ransum K1 memiliki hasil pengukuran yang lebih tinggi dari $\mathrm{K} 2$, serta pemberian pakan dua kali memiliki pengukuran denyut nadi yang lebih rendah dari pemberian pakan tiga atau empat kali. Hal tersebut kemungkinan karena domba kebutuhan metabolisme tubuhnya. K1 mempunyai Hasil rataan denyut nadi domba lokal disajikan pada Tabel 3.

Denyut nadi nyata $(\mathrm{P}<0.05)$ dipengaruhi oleh interaksi frekuensi pemberian pakan dan taraf perbandingan konsentrat pada siang hari. Domba yang diberi pakan dua kali dengan ransum K2, memiliki hasil yang sama dengan domba yang diberi pakan dua kali dan empat kali dengan ransum K1, serta berbeda dengan domba yang diberi pakan tiga kali dengan ransum K1 maupun K2, serta berbeda pula dengan domba yang diberi pakan empat kali dengan ransum K2. Domba yang diberi pakan tiga kali dengan ransum K1 maupun K2 memiliki hasil yang sama dengan domba yang diberi ransum $\mathrm{K} 1$ dengan dua dan empat kali pemberian pakan, serta sama dengan domba yang diberi pakan empat kali dengan ransum K2, akan tetapi berbeda dengan domba yang diberi pakan dua kali dengan ransum K2. Denyut nadi juga nyata $(\mathrm{P}<0.05)$ dipengaruhi oleh konsentrat pada sore hari, yaitu domba yang diberi ransum K1 berbeda dengan domba yang diberi ransum K2. Denyut nadi domba akan mempunyai laju yang lebih tinggi ketika metabolisme tubuhnya memerlukan adanya pelepasan panas tubuh. Produksi panas tubuh secara homeostatis akan dilepaskan oleh ternak untuk mencapai titik nyamannya. Salah satu mekanisme tersebut adalah dengan meningkatkan laju aliran darah sehingga denyut nadi menjadi meningkat.

\section{Suhu Rektal}

Suhu tubuh hewan berdarah panas (homeotermi) merupakan hasil keseimbangan dari panas yang diterima dan dikeluarkan oleh tubuh. Suhu tubuh dapat diamati melalui suhu rektal, karena suhu rektal merupakan indikator yang baik untuk menggambarkan suhu internal tubuh ternak. Data rataan suhu rektal pada domba UP3J dengan perlakuan pemberian frekuensi pakan dan taraf perbandingan konsentrat yang berbeda disajikan pada Tabel 4.

Berdasarkan pengukuran yang dilakukan, rataan suhu rektal domba UP3J masih dalam kisaran normal. Smith dan Mangkoewidjojo (1988) menyatakan, bahwa suhu rektal normal pada domba di daerah tropis berkisar antara $38.2-40{ }^{\circ} \mathrm{C}$.

Rata-rata suhu rektal pada pagi hari $(39.12 \pm 0.28$ $\left.{ }^{\circ} \mathrm{C}\right)$ lebih rendah dari siang $\left(39.38 \pm 0.23{ }^{\circ} \mathrm{C}\right)$ dan sore hari $\left(39.61 \pm 0.30^{\circ} \mathrm{C}\right)$. Hal ini sesuai dengan pernyataan Edey (1983) bahwa suhu rektal harian, pada pagi hari rendah sedangkan pada siang hari tinggi. Hasil pengukuran juga menunjukkan, bahwa rataan suhu rektal domba yang diberi ransum K1 memiliki hasil pengukuran yang lebih tinggi dari 
$\mathrm{K} 2$, serta pemberian pakan tiga kali memiliki pengukuran suhu rektal yang lebih rendah dari pemberian pakan dua atau empat kali.

Suhu rektal nyata $(\mathrm{P}<0.05)$ dipengaruhi oleh interaksi antara frekuensi pemberian pakan dan taraf perbandingan konsentrat pada sore hari. Domba yang diberi pakan tiga kali dengan ransum K2 memiliki hasil yang paling rendah. Hal tersebut dapat disebabkan pakan K2 mempunyai energi yang lebih tinggi sehingga panas metabolisme tubuh yang lebih tinggi, sehingga suhu tubuh domba menjadi lebih tinggi. Hal ini tidak berpengaruh terhadap kondisi domba dikarenakan hasil pengukuran suhu rektal domba UP3J masih dalam kisaran normal.

\section{KESIMPULAN}

Kesimpulan dari penelitian ini adalah frekuensi pemberian pakan, taraf perbandingan konsentrat dan waktu pengamatan berpengaruh terhadap respon fisiologis domba UP3J (suhu rektal sore hari, denyut nadi siang dan sore hari, dan respirasi pagi hari). Domba yang diberi pakan tiga kali memiliki respon fisiologis yang lebih rendah dari domba yang diberi pakan dua atau empat kali pada suhu rektal dan respirasi, sedangkan respon fisiologis lebih rendah pada denyut nadi saat domba diberi pakan dua kali. Domba yang diberi ransum $\mathrm{K} 1$ memiliki respon fisiologis yang lebih tinggi dari ransum K2 pada suhu rektal dan denyut nadi, sedangkan ransum K1 memiliki respon fisiologis yang lebih rendah dari ransum $\mathrm{K} 2$ pada respirasi.

\section{DAFTAR PUSTAKA}

Adelodun O, Fadare, Sunday O, Peters, Abdulmojeed Y, Adekayode O, Sonibare, Matthew A, Adeleke, Michael O 2012. Physiological and haematological indices suggest superior heat tolerance of white-coloured West African Dwarf sheep in the hot humid tropics. J Trop Anim Health Prod. 10:1-9.doi 10.1007/s11250-0120187-0.

Al-Tamimi HJ. 2007. Thermoregulatory response of goat kids subjected to heat stress. Small Ruminant Research.71:280-285.

Anjani EP. 2013. Tingkah laku dan respon fisiologis domba ekor gemuk yang dicukur dan diberi tambahan pakan ampas tahu [skripsi]. Bogor (ID): Institut Pertanian Bogor.

Baratawidjaja, Karnen G. 2004. Imunologi Dasar. Jakarta (ID): UI Pr.

Bhatta R, Kumar V, Sridhar M, Singh K. 2006. Energy expenditure in crossbred cattle fed paddy straw of different form Asian-Aust. J. Anim. Sci. 19:1755-1760.

[Ditjen PKH] Direktorat Jendral Peternakan dan Kesehatan Hewan Kementrian Pertanian RI. 2018. Statistika Peternakan dan Kesehatan Hewan 2018. Jakarta (ID): Direktorat Jendral Peternakan dan Kesehatan Hewan Kementrian Pertanian RI.

Edey TN. 1983. The Genetic pool of sheep and goats. Dalam: Goat and Sheep Production in The Tropics. ELBS. Longman Group Ltd, Essex.
Frandson RD. 1992. Anatomi dan Fisiologi Ternak. Yogyakarta (ID): Gadjah Mada University Pr.

Hafez MAM. 2002. Studies on the productive performance in sheep [tesis]. Egypt (EG): Zagazig University.

Handoko. 1995. Klimatologi Dasar. Jakarta (ID): Pustaka Jaya.

Isnaeni W. 2006. Fisiologi Hewan. Jakarta (ID): Kanisius.

Isroli SA, Santoso B, Haryati N. 2004. Respon termoregulasi dan kadar urea darah domba garut betina dewasa yang dipelihara di dataran tinggi terhadap pencukuran woll. Jurnal Pengembangan Peternakan Tropis. 2:110-114.

Jain NC. 1993. Essentials of Veterinary Hematology. Philadelphia (US): Lea and Febiger. hlm 732-752.

Marai I, El-Darawany AA, Fadiel A, Abdel-Havez HAM. 2007. Physiological traits as affected by heat stress in sheep. Small Ruminant Research. 71:1-12.

Mathius IW, Yulistiani D, Wina E, Haryanto B, Wilson A, Thalib A, 2001. Pemanfaatan energi terlindung untuk meningkatkan efisiensi pakan pada domba induk. Jurnal Ilmu Ternak dan Veteriner. 6(1):7-13.

Panagakis P. 2011. Black-globe temperature effect on short-term heat stress of dairy ewes housed under hot weather conditions. Small Ruminant Research. 100:96-99.

Rahayu S, Diapari D, Wandito DS, Ifafah WW. 2010. Survey potensi ketersediaan limbah taoge sebagai pakan ternak alternatif di Kota Bogor. Laporan Penelitian. Departemen Ilmu Produksi dan Teknologi Peternakan, Fakultas Peternakan, Institut Pertanian Bogor, Bogor.

Salsabila SS, Rahayu S, Putra BW. 2014. Respon fisiologis dan tingkah laku domba garut jantan dengan pakan dan manajemen pemberian pakan berbeda [skripsi]. Bogor (ID): Institut Pertanian Bogor.

Silanikove N. 2000. Effects of heat stress on the welfare of extensively managed domestic ruminants. $J$ Livestock Production Sci. 67:(1-2), 1-18.

Smith JB, Mangkoewiidjojo S. 1988. Pemeliharaan, Pembiakan dan Penggunaan Hewan Percobaan di Daerah Tropis. Jakarta (ID): Universitas Indonesia Pr.

Sumantri C, Eintiana A, Salamena JF, Inounu I. 2007. Keragaman dan hubungan phylogenik antar domba lokal di Indonesia melalui pendekatan analisis morfologi. JITV. 12(1):42-54.

Sumoprastowo RM. 1986. Beternak Kambing yang Berhasil. Jakarta (ID): Bhatara Karya.

Thahirah E, Rahayu S, Baihaqi M. 2019. Performa domba UP3J dengan freskuensi pakan dan taraf konsentrat yang berbeda [skripsi]. Bogor (ID): Institut Pertanian Bogor.

Widjajakusuma R, Sikar SH. 1986. Fisiologi Hewan Jilid II. Fisiologi dan Farmakologi. Bogor (ID): FKH-IPB.

Wilson JA. 1979. Principle of Animal Phisiology. 2nd Edition. New York(USA): MacMilan Publisher.

Yousef MK. 1985. Stress Physiology in Livestock. Florida (US): CRC Press. Inc. Boca Raton. 